OPEN ACCESS

Edited by:

Robert Jeenchen Chen,

The Ohio State University,

United States

Reviewed by:

Bleri Celmeta,

Istituto Clinico Sant'Ambrogio, Italy

Michael Hofmann,

University of Zurich, Switzerland

${ }^{*}$ Correspondence:

Zhongshi Wu

owenzswu@csu.edu.cn orcid.org/0000-0003-2720-8381

Specialty section:

This article was submitted to

Heart Surgery

a section of the journal

Frontiers in Surgery

Received: 03 June 2021

Accepted: 11 August 2021

Published: 22 September 2021

Citation:

Qian T, Yuan H, Chen C, Liu Y, Lu T, Huang $C$ and $W u Z$ (2021) Conduits for Right Ventricular Outflow Tract Reconstruction in Infants and Young Children. Front. Surg. 8:719840. doi: 10.3389/fsurg.2021.719840

\section{Conduits for Right Ventricular Outflow Tract Reconstruction in Infants and Young Children}

\author{
Tao Qian ${ }^{1,2}$, Haoyong Yuan ${ }^{1,2}$, Chunyang Chen ${ }^{1,2}$, Yuhong Liu ${ }^{1,2}$, Ting Lu ${ }^{1,2}$, Can Huang ${ }^{1,2}$ \\ and Zhongshi $W^{1,2 *}$ \\ 1 Department of Cardiovascular Surgery, The Second Xiangya Hospital, Central South University, Changsha, China, \\ ${ }^{2}$ Engineering Laboratory of Hunan Province for Cardiovascular Biomaterials, Changsha, China
}

Purpose of Review: Right ventricular outflow tract (RVOT) reconstruction remains a challenge due to the lack of an ideal conduit. Data and experience are accumulating with each passing day. Therefore, it is necessary to review this topic from time to time. This is a 2021 update review focused on the history, evolution, and current situation of small-sized conduits ( $\leq 16 \mathrm{~mm}$ ) for RVOT reconstruction in infants and young children.

Recent Findings: Currently, the available small-sized $(\leq 16 \mathrm{~mm})$ conduits can meet most clinical needs. Homograft is still a reliable choice for infants and young children validated by a half-century clinical experience. As an alternative material, bovine jugular vein conduit (BJVC) has at least comparable durability with that of homograft. The performance of expanded polytetrafluoroethylene (ePTFE) is amazing in RVOT position according to limited published data. The past century has witnessed much progress in the materials for RVOT reconstruction. However, lack of growth potential is the dilemma for small-sized conduits. Tissue-engineering based on cell-free scaffolds is the most promising technology to obtain the ideal conduit.

Summary: No conduit has proved to have lifelong durability in RVOT position. We are far from the ideal, but we are not in a state of emergency. In-depth clinical research as well as innovation in material science are needed to help improve the durability of the conduits used in infants and young children.

Keywords: right ventricular outflow react reconstruction, valved conduit, children, homograft, bovine jugular vein conduit, expanded polytetrafluoroethylene, tissue engineering

\section{INTRODUCTION}

Despite developments in materials science, we still do not have an ideal valved conduit for right ventricular outflow tract (RVOT) reconstruction (1). Currently, no conduit can meet the long-term functional requirements, especially the small-sized $(\leq 16 \mathrm{~mm})$ conduit used in infants and young children. In addition, the standard surgical timing of critical congenital heart disease has shifted to an earlier stage, with most patients having surgical treatment in the first year after birth (2). Furthermore, the Ross operation has been widely applied in pediatric patients (3). The demand for small-sized conduits has been ever-increasing.

Cryopreserved pulmonary homograft had been regarded as the gold standard materials for RVOT reconstruction for a long period of time. However, in addition to its inadequate durability 
(4-6), small-sized homograft is in a severe shortage. Besides, the second homograft usually performed much worse than that of the first one in the same patient (7). These issues have pushed us to explore alternative materials for RVOT reconstruction. One way to help deal with the shortage of small-sized conduits is the down-sized technique (8). We were pleased to find that this technique does not affect the the function and durability of the conduits $(9,10)$. There is no doubt that the bovine jugular vein conduit (BJVC), usually known as Contegra ${ }^{\circledR}$ conduit (Medtronic Inc., Minneapolis, Minnesota, USA), has achieved great success. It showed comparable $(11,12)$ or even better (13-15) performance than homograft. Still, the durability of BJVC is very poor in infants (16). To make matters worse, the Contegra conduit had not been authorized for profit upon sale until 2013 and is still not available in China and other countries. Recently, the Japanese approach of hand-sewn expanded polytetrafluoroethylene (ePTFE) valved conduit has attracted much attention, with excellent long-term outcomes demonstrated in multi-center studies where more than $90 \%$ small-sized conduits were free from explantation at 5 years (1719). However, very limited numbers of heart centers outside of Japan reported the application of this conduit, perhaps due to the inconsistent quality control of a hand-sewn valve.

An ideal conduit should be one with permanent physiological functions and with growth potential adapting to the patient's somatic growth. That is, the conduit should be "alive" in the host. The development of tissue engineering technology provides us with the opportunity to realize the ideal. In this review, we focus on the history evolution and current situation of smallsized conduits ( $\leq 16 \mathrm{~mm}$ ) for RVOT reconstruction in infants and young children. The difficulties as well as the future direction will be discussed to provide assistance for the development of pulmonary valved conduits.

\section{HISTORY}

The history timeline of available small-sized conduits is shown in Figure 1. In the development of conduit materials for RVOT reconstruction, the valveless conduit was the first attempt and is worthy of being mentioned. It was reported as serving as the RVOT material in REV (Réparation à l'Etage Ventriculaire) operations and truncus arteriosus repair $(20,21)$. However, most centers now prefer a valved conduit due to the undoubted importance of functional pulmonary valve.

The homograft conduit constitutes a crucial part in the history of pulmonary conduits (22). It is the first and most widely used valved conduit for ROVT reconstruction. During the past half-century, the improvement of processing and preserving technology has facilitated superior durability for homograft (8, 23, 24). Down-sized technique makes up for the shortage of homograft for young children and has achieved satisfactory durability. But none of them can achieve lifelong durability and therefore serve as a palliative treatment for young children. Later on, many xenografts were introduced for RVOT reconstruction, but only a few of them are suitable for infants and young children. The Hancock ${ }^{\circledR}$ conduit (Medtronic Inc., Minneapolis,
Minnesota, USA) is the first commercial xenograft which consisted of porcine valve sutured into a Dacron conduit. The Contegra conduit (Medtronic Inc.) is one of the most successful xenografts which was mainly treated with glutaraldehyde. The xenografts were easier to obtain with much lower cost than homografts, but still, without much improvement in durability, particularly for young children. The Japanese approach of handsewn ePTFE valves is a great event in the history of conduits (25). Japanese researchers have established a mature system for the construction of hand-made ePTFE valved conduits and achieved amazing clinical outcomes.

Throughout history, we have achieved great success in conduit materials' evolution for RVOT reconstruction in young children. Currently, the available conduits (Table 1) can meet the clinical needs in most countries, and re-thoracotomy for conduit replacement is no longer a high-risk operation for cardiac surgeons. Moreover, trans-catheter pulmonary valve replacement (TPVR) has been proven to be a safe and effective therapeutic for failed pulmonary conduits (34). Therefore, our current task is to improve the durability and prolong the life of the valved conduit for RVOT reconstruction. We are far from the ideal, but we are not in a state of emergency.

\section{CLINICAL OUTCOMES OF AVAILABLE CONDUITS}

\section{Homograft}

Generally, cryopreserved homograft conduits perform much better in adults than in childrens, as well as in Ross operations than in non-Ross operations $(35,36)$. As detailed in Table 1, only a few studies analyzed the durability in infant or young children subgroups.

Kaza et al. found only $6.7 \%$ of pulmonary homograft conduits were free from reintervention at 14 years in newborns who underwent surgical repair of tetralogy of Fallot and truncus arteriosus. On the other hand, all aortic homograft conduits were replaced within 10 years (37). Brown et al. reported their experience of homograft in 117 non-Ross operations, in which nearly half of the patients were infants $(n=57,49 \%)$ (5). The freedom from homograft failure (defined as reintervention or patient death) was $42 \%$ at 5 years and $34 \%$ at 15 years. Another study focused on the fate of small-sized homograft in non-Ross operations revealed that almost all homograft conduits smaller than $12 \mathrm{~mm}$ had to be replaced within 3 years (26). The 5year freedom from replacement was approximately $10 \%$ and $30 \%$ respectively for conduits with diameters of $12-14$ and 15$17 \mathrm{~mm}$ (26). The long-term results of cryopreserved homograft implanted in Ross operations in infants were reported by Nelson et al. (27). The freedom from homograft reintervention for 44 infants in this cohort was $52 \%$ at 5 years and $19 \%$ at 15 years.

The down-sized technique was first described by Michler et al. in 1994, obtaining a bicuspid valved conduit by removing one of the three valve leaflets and the attached wall (8). The largest study cohort of down-sized homograft conduits came from the German Heart Centre, Munich (9). Eighty-two patients receiving a down-sized homograft were compared to 70 patients 


\begin{tabular}{|c|c|c|c|c|c|c|}
\hline & & \multicolumn{2}{|c|}{$\begin{array}{l}\text { Tissue-engineered } \\
\text { vascular graft }\end{array}$} & \multicolumn{2}{|c|}{$\begin{array}{c}\text { Decellularized technology } \\
\text { SynerGraft }{ }^{\circledR}\end{array}$} & $\begin{array}{c}\text { Hannover group } \\
\text { Decellularized } \\
\text { fresh homograft }\end{array}$ \\
\hline & & & & \multicolumn{2}{|r|}{1999} & 2002 \\
\hline 1964 & 1966 & 1972 & 1987 & 1994 & 1999 & 2021 \\
\hline $\begin{array}{l}\text { Nonvalved } \\
\text { conduit }\end{array}$ & Homograft & $\begin{array}{c}\text { Hancock }{ }^{\circledR} \\
\text { conduit }\end{array}$ & $\begin{array}{l}\text { Cryopreserved } \\
\text { homograft }\end{array}$ & $\begin{array}{l}\text { Down-sized } \\
\text { homograft }\end{array}$ & $\begin{array}{l}\text { Contegra }{ }^{\circledR} \\
\text { conduit }\end{array}$ & $\begin{array}{l}\text { TFE } \\
\text { conduit }\end{array}$ \\
\hline $\begin{array}{l}\text { Rastelli } \\
(1933-1970)\end{array}$ & $\begin{array}{c}\text { Ross } \\
(1922-2014)\end{array}$ & & O'Brien & Michler & Yamagis & nd Miyazaki \\
\hline
\end{tabular}

receiving normal small-sized homograft. Both the mean conduit diameter and the freedom from replacement were comparable in the two groups ( 14.8 vs. $14.6 \mathrm{~mm}$; 69 vs. $61 \%$ at 10 years). Romeo et al. reported similar results in patients under 2-yearsold (10). More recently, Francois et al. finished another study focused on the comparison between down-sized homograft and other conduits in patients under 3-years-old (28). The freedom from structural valve degeneration (SVD, defined as conduit dysfunction or replacement) at 10 years was 68,42 , and $31 \%$ for pulmonary homograft, down-sized homograft, and aortic homograft, respectively. Multivariable analysis confirmed the down-sized technique did not increase the risk of SVD.

There is no doubt that the cryopreserved homograft is immunogenic as the cryopreserved technology retained lots of allogeneic cells (29). The graft-related immune response plays an important role in the failure of cryopreserved homograft in young children (38). A response to the immunogenicity was decellularized technology (SynerGraft, CryoLife, Kennesaw, GA) proposed by O'Brien in 1999 (24). Decellularization preserves the extracellular matrix scaffold while greatly eliminating the immunogenicity from allogeneic cells, resulting in a milder immune reaction in the host. Ruzmetov et al. compared decellularized and standard cryopreserved homograft inserted primarily in patients $<1$ year old, as part of their single-institution study (39). Both the 10-year freedom from replacement and reintervention of the decellularized homograft trended better. A multicenter study demonstrated significantly higher durability of the SynerGraft homograft conduit compared with that of standard cryopreserved homograft (40). The decellularized fresh homografts developed by the Hannover group were first applied after pre-seeding of endothelial progenitor cells for two pediatric patients in 2002 (41). The conduits have been widely used in Europe (the ESPOIR Trial) without pre-seeding of stem cells $(30,33,42)$. The latest longterm follow-up results showed significantly better freedom from explantation and less structural valve degeneration when matched to cryopreserved homograft and BJVC (42). The decellularized homograft is expected to be a better choice for infants and young children, but needs more evidence from large samples with longer follow-ups.

\section{Bovine Jugular Vein Conduit}

The BJVC, usually known as Contegra ${ }^{\circledR}$ conduit, was introduced as a substitute to homograft. Patel and Brown et al. reported the freedom from BJVC explantation was $53 \%$ at 5 years and $15 \%$ at 10 years for infants (16). The mean time to conduit failure was 5.2 years in the infants subgroup and 5.8 years in the smallsized conduits (12-14 mm) subgroup (16). Germany took the lead in clinical use of BJVC. Later on, a series of multicenter studies were carried out. The latest multicenter study revealed that the BJVC performed much better than homograft in infants. In fact, about $90 \%$ of the BJVC became dysfunctional 10 years after implantation, while a similar outcome only took 4 years in homograft recipients (43). The Congenital Heart Surgeons Society reported a series of high-impact multicenter studies on the conduits for RVOT reconstruction in young children $(13,31,44)$. Their recommendation of oversizing conduits with $\mathrm{z}$-scores between +1 and +3 is still widely acknowledged today (31). Two other studies also demonstrated that BJVC has better performance than homograft in infants and young children $(13,44)$.

Recently, the durability of BJVC and homograft have been further compared in strictly matched newborns (12, 14, 44, 45). One multicenter study included three groups using different conduits (83 pulmonary homograft conduits, 53 aortic homograft conduits, and 55 BJVCs) in truncus arteriosus repair (45). The study found that, although the three groups showed similar portions of replacement, the reintervention of BJVC was significantly less than homograft conduit. A similar conclusion was reported in another long-term longitudinal study of patients with truncus arteriosus (14). More than 20\% of BJVC was free from reoperation at 10 years, while less than $10 \%$ of pulmonary homograft conduits and no aortic homograft conduit were free from reintervention (14). 
TABLE 1 | Clinical results of small-sized valved conduits for right ventricular outflow tract reconstruction in infants and young children.

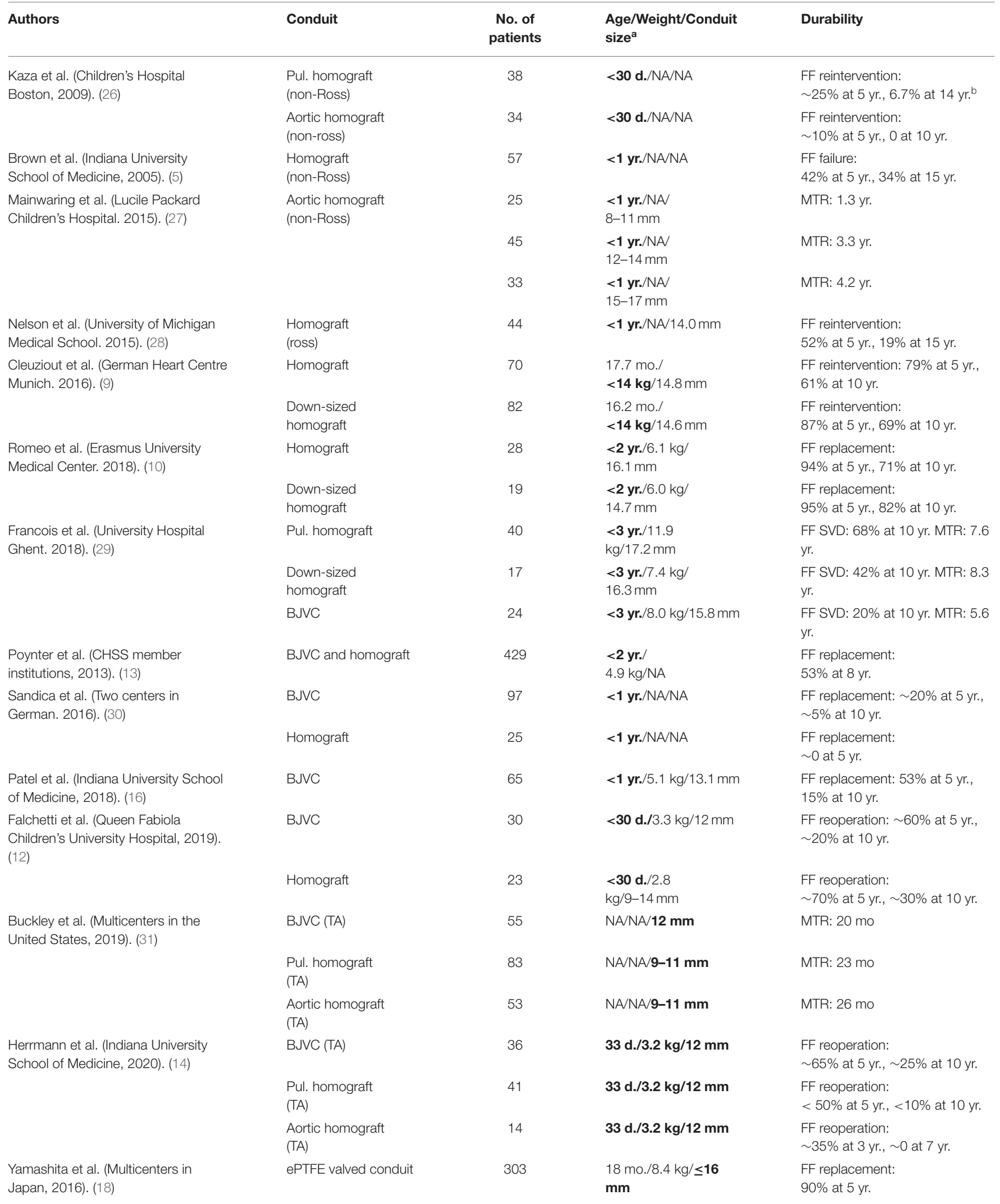


TABLE 1 | Continued

\begin{tabular}{|c|c|c|c|c|}
\hline Authors & Conduit & $\begin{array}{l}\text { No. of } \\
\text { patients }\end{array}$ & $\begin{array}{l}\text { Age/Weight/Conduit } \\
\text { size }^{\text {a }}\end{array}$ & Durability \\
\hline \multirow[t]{2}{*}{$\begin{array}{l}\text { Miyazaki et al. (Multicenters in Japan, } \\
\text { 2018). (19) }\end{array}$} & ePTFE valved conduit & 292 & $<2$ yr./12.6kg/NA & $\begin{array}{l}\text { FF replacement: } 90 \% \text { at } 5 \text { yr., } \\
74 \% \text { at } 10 \text { yr. }\end{array}$ \\
\hline & ePTFE valved conduit & 400 & $\mathrm{NA} / \mathrm{NA} / \leq 16 \mathrm{~mm}$ & $\begin{array}{l}\text { FF replacement: } \\
92 \% \text { at } 5 \text { yr., } 76 \% \text { at } 10 \mathrm{yr} .\end{array}$ \\
\hline \multirow[t]{2}{*}{$\begin{array}{l}\text { Mercer et al. (Children's Hospital of } \\
\text { Pittsburgh, 2018). (32) }\end{array}$} & $\begin{array}{l}\text { Bicuspid ePTFE valved } \\
\text { conduit }\end{array}$ & 39 & $<2$ yr. $/ 5.7 \mathrm{~kg} / 11.8 \mathrm{~mm}$ & $\begin{array}{l}\text { Incidence of replacement: } \\
17 \% \text { at } 1 \text { yr., } 55 \% \text { at } 5 \text { yr. }\end{array}$ \\
\hline & Homograft & 26 & $<2$ yr. $/ 5.6 \mathrm{~kg} / 11.2 \mathrm{~mm}$ & $\begin{array}{l}\text { Incidence of replacement: } \\
23 \% \text { at } 1 \text { yr., } 56 \% \text { at } 5 \text { yr. }\end{array}$ \\
\hline \multirow[t]{2}{*}{$\begin{array}{l}\text { Seese et al. (Children's Hospital of } \\
\text { Pittsburgh, 2020). (1) }\end{array}$} & $\begin{array}{l}\text { Bicuspid ePTFE valved } \\
\text { conduit (TA) }\end{array}$ & 18 & $<\mathbf{3 0}$ d./NA/11 mm & $\begin{array}{l}\text { FF replacement: } \\
82 \% \text { at } 5 \text { yr., } 27 \% \text { at } 10 \mathrm{yr} .\end{array}$ \\
\hline & $\begin{array}{l}\text { Homograft } \\
\text { (TA) }\end{array}$ & 7 & $<\mathbf{3 0}$ d./NA/10 mm & $\begin{array}{l}\text { FF replacement: } \\
71 \% \text { at } 5 \text { yr., } 29 \% \text { at } 10 \mathrm{yr} .\end{array}$ \\
\hline \multirow[t]{3}{*}{$\begin{array}{l}\text { Vitanova et al. (German Heart Centre } \\
\text { Munich, 2014). (11) }\end{array}$} & Hancock conduit & 48 & $<1$ yr. $/ 4.3 \mathrm{~kg} / \leq 14 \mathrm{~mm}$ & $\begin{array}{l}\text { FF replacement: } \\
54 \% \text { at } 5 \text { yr., } 20 \% \text { at } 10 \mathrm{yr} .\end{array}$ \\
\hline & Homograft & 62 & $<1$ yr. $/ 4.6 \mathrm{~kg} / \leq 16 \mathrm{~mm}$ & $\begin{array}{l}\text { FF replacement: } \\
69 \% \text { at } 5 \text { yr., } 38 \% \text { at } 10 \mathrm{yr} \text {. }\end{array}$ \\
\hline & BJVC & 35 & $<1$ yr. $/ 4.2 \mathrm{~kg} / \leq 16 \mathrm{~mm}$ & $\begin{array}{l}\text { FF replacement: } \\
59 \% \text { at } 5 \text { yr., } 38 \% \text { at } 10 \mathrm{yr} .\end{array}$ \\
\hline \multirow[t]{2}{*}{$\begin{array}{l}\text { Ruzmetov et al. (Children's Hospital of } \\
\text { Illinois, 2012). (33) }\end{array}$} & $\begin{array}{l}\text { Decellularized } \\
\text { homograft }\end{array}$ & 6 & $<1$ yr./NA/NA & FF replacement: $67 \%$ at $10 \mathrm{yr}$. \\
\hline & Homograft & 17 & $<1$ yr./NA/NA & $\begin{array}{l}\text { FF replacement: } \\
25 \% \text { at } 10 \mathrm{yr} \text {. }\end{array}$ \\
\hline
\end{tabular}

a Values of age/weight/conduit size are mean or median or range. The bold words indicate the main characteristics of the study cohort.

$\boldsymbol{b}$ " " indicates the value was obtained according to the survival curve in the literature.

BJVC, bovine jugular vein conduit; CHSS, the Congenital Heart Surgeons Society; ePTFE, expanded polytetrafluoroethylene; FF, freedom from; MTR, mean/median time to replace; NA, not available; Pul., pulmonary; SVD, structural valve degeneration; TA, truncus arteriosus.

As detailed in Table 1, the highest rate of 10 -year freedom from BJVC replacement was approximately $25 \%$ in young children $(12,14)$. Although the results from different studies were not consistent, the BJVC showed similar or even better durability than that of cryopreserved homograft for RVOT reconstruction. However, the BJVC has greater incidence of late endocarditis after being implanted, with a rate of $4.7 \%$ to $9.9 \%$ reported in previous studies $(16,46-48)$. The endocarditis seems to be a unique situation that occurs in glutaraldehyde-treated bovine jugular vein products (49). The reasons are still unclear, but the infection will definitely exacerbate the failure of the conduit.

\section{The Hand-Made ePTFE Valved Conduit}

The $0.1 \mathrm{~mm}$ thick ePTFE has been employed as the pulmonary valve material since the 1990s (50, 51). Yamagishi, Miyazaki, and colleagues carried out a series of impressive technological innovations in Japan, contributing to the hand-made ePTFE valved conduit which consisted of three bulging sinuses and tricuspid fan-shaped valve $(17,52)$.

In Japan, the ePTFE valve is preferred in the form of a conduit instead of the originally designed valved patch (53), as they found that even the small-sized $(\leq 16 \mathrm{~mm})$ conduits had satisfactory durability (18). A nationwide multicenter study revealed that $90.1 \%$ small-sized ePTFE valved conduits were free from replacement at 5 years (18). More recently, another nationwide multicenter study in Japan incorporated 292 patients of $<2$ years of age and found that the freedom from replacement was $90 \%$ at 5 years, $74 \%$ at 10 years, and $67 \%$ at 12 years (19). When examined by conduit diameter, the freedom from small-sized conduit replacement was $76 \%$ at 10 years (19).

The clinical results from Japan were excellent. However, this artificial conduit was only used in a handful of heart centers outside of Japan $(54,55)$. In the last decade, the application of $0.1 \mathrm{~mm}$ thick ePTFE for RVOT reconstruction has gradually increased in the form of bicuspid valves directly sutured into RVOT $(56,57)$, or bicuspid/tricuspid valved conduits without bulging sinuses $(32,58)$. Mercer et al. reported a similar performance for bicuspid ePTFE valved conduits with homograft conduits in patients $<2$ years of age (59). Another study from this team focusing on neonatal truncus arteriosus repair also showed similar durability, with 10-year freedom from replacement of 27.3 and $28.5 \%$ respectively for ePTFE valved conduit and homograft conduit (60).

Despite remaining controversial, the introduction of handsewn ePTFE valved conduits for RVOT reconstruction is a great innovation. Current data show that it has a high tendency to become another successful substitute for pulmonary conduit.

\section{Other Conduits}

The Hancock ${ }^{\circledR}$ conduit (Medtronic Inc.) is the oldest xenogeneic valved conduit which is still in use. Vitanova et al. reported the freedom from Hancock conduit replacement of $53.8 \%$ at 5 years and $20.3 \%$ at 10 years, which was similar to that of homograft and BJVC in young children (11). To the best of our knowledge, other 
xenografts, including the Carpentier-Edwards conduit (Edwards Lifesciences, Irvine, California, USA), Freestyle porcine aortic root (Medtronic Inc.), and stented bioprosthetic valves, were rarely reported as being used in infants and young children. In the past 10 years, TPVR has emerged as an alternative to openheart surgery in selected patients (61). This technology has not been applied in infants or young children. However, conduits like Hancock have been identified to be more favorable for future TPVR and thus have been more used.

Another alternative allograft for RVOT reconstruction in infants is valved femoral vein homograft $(\mathrm{FVH})$. Sinha et al. reported the first case of a 2-month-old girl diagnosed with Fallot with pulmonary atresia in 2008 (62). By the end of 2012, they had implanted a total of 20 FVHs in neonates and infants and found a lower rate of both reintervention and reoperation compared with homograft in the short- to mid-term (63). Theoretically, FVH has thinner walls and fewer donor cell components, which is beneficial to the infiltration and growth of host cells after implantation. Carreon et al. found that 1 year after being implanted as a pulmonary conduit, the venous walls underwent remodeling with only minimal inflammation and calcification, and the venous valve leaflets were relatively spared from hyperplasia with preserved function (64). However, more studies are required to explore the fate of FVH in RVOT position.

Tissue engineering valved conduits is a perfect technology assumption, which is supposed to achieve lifelong functional requirements through in-vitro cell seeding and culturing, bioprinting, or in-vivo regeneration approaches (65). It seems to be more feasible to induce remodeling in vivo based on the cellfree natural scaffolds or synthetic biodegradable materials, other than in-vitro cell culturing (66). Significant efforts have been put into the synthetic biodegradable valved conduit scaffolds $(67,68)$. Bennink et al. recently reported the outcomes of an animal experiment of a synthetic biodegradable conduit processed by electrospinning (69). Over a 1 year follow-up period, the pulmonary conduits were progressively remolded and degraded with stable functionality in the sheep model. The CorMatrix ${ }^{\circledR}$ conduit (CorMatrix Cardiovascular, Inc., Roswell, USA) is a biodegradable natural scaffold composed of porcine small intestinal submucosa extracellular matrix (70). Unfortunately, it failed to remodel as a pulmonary conduit before the valve degeneration in both porcine model and xenogeneic animal model $(71,72)$. Ghorbel et al. seeded the mesenchymal stem cellderived vascular smooth muscle cells in vitro into the CorMatrix conduit (73). Six months after being implanted to reconstruct the left pulmonary artery in piglets, the cellularized-CorMatrix grafts were remolded with homogeneous endothelium covered by multi-layered muscular media (73).

In our institution, we have been devoted to research on BJVC since 2002. During this time, we successfully developed a novel decellularized and photo-oxidatively crosslinked BJVC (74-76). This conduit is a cell-free xenogeneic scaffold conducive to host cells' attachment and growth. After a series of strict large animal experiments, it has been put into clinical application in several centers in China. The 10-year freedom from conduit replacement and catheter-based reintervention were $94.7 \%$ and $52.9 \%$, respectively, for children $\leq 3$ years old (77).

\section{FUTURE DIRECTION}

An ideal pulmonary conduit for reconstruction of RVOT should be "alive": composed of viable host cells, equipped with stable functionality, and able to grow with the patient's somatic growth synchronously. Tissue-engineered conduits are expected to meet all of the requirements to make it an ideal conduit. After decades of exploration, however, this technology is still in its infancy.

It seems that we have not made a substantial breakthrough in conduit materials for RVOT reconstruction, especially in conduits for infants and young children. Lacking in growth potential is an issue that seems insurmountable at present. For adults, we actually do not need an "alive" conduit due to the non-obvious somatic alterations, as long as one conduit can maintain long-term structure stability and functionality. The ePTFE valved conduit therefore may provide greater durability than biological grafts in adults, as it is biologically inert and resistant to immunological degeneration. For children, several studies concluded that somatic outgrowth is not the core reason for the failure of pulmonary conduit $(6,7)$, that is, the conduit has failed even before its mismatch. Children may also benefit from biologically inert conduits.

The development of novel pulmonary valved conduits based on tissue engineering technology is the most promising way to tackle the dilemma. In addition, modification based on the currently available conduits, such as the preservation technique for homograft, anti-calcification, and anti-infection modification of glutaraldehyde-treated BJVC, may help to achieve better durability. In addition, large multicenter studies, rigorous meta-analysis focused on specific concerns, and comparisons between different conduits in certain conditions might be helpful to establish unified standards for pulmonary valved conduit implantation.

\section{CONCLUSION}

We still do not have an ideal valved conduit for RVOT reconstruction in infants and young children. But fortunately, the available small-sized conduits can meet most of the clinical demand. Homograft and BJVC are still reliable choices for young children. Hand-made ePTFE valved conduits have very satisfactory performance based on currently limited reported data. Innovation in material science and more in-depth clinical studies in this special field are required to get better durability. Tissue engineering technology based on cell-free scaffolds is still the most promising way to obtain an ideal "alive" valved conduit, but there is still a long way to go.

\section{AUTHOR CONTRIBUTIONS}

ZW make substantial contributions to conception and design, and give final approval of the version to be submitted. TQ drafted and revised the manuscript. HY, CC, YL, TL, and $\mathrm{CH}$ participate in revising the manuscript critically for important intellectual content. All the authors have contributed significantly to the review. 


\section{REFERENCES}

1. Costa F. Conduits for right ventricular outflow tract reconstruction in children: are we improving? World J Pediatr Congenit Heart Surg. (2020) 11:148-9. doi: 10.1177/2150135119892935

2. Mavroudis C, Backer C, Idriss RF (eds.). Pediatric Cardiac Surgery, 4th Edn. Oxford: Blackwell Publishing Ltd (2012). doi: 10.1002/9781118320754.ch5

3. Luciani GB, Lucchese G, Carotti A, Brancaccio G, Abbruzzese P, Caianiello $\mathrm{G}$, et al. Two decades of experience with the Ross operation in neonates, infants and children from the Italian Paediatric Ross Registry. Heart. (2014) 100:1954-9. doi: 10.1136/heartjnl-2014-305873

4. Selamet Tierney ES, Gersony WM, Altmann K, Solowiejczyk DE, Bevilacqua LM, Khan C, et al. Pulmonary position cryopreserved homografts: durability in pediatric Ross and non-Ross patients. J Thorac Cardiovasc Surg. (2005) 130:282-6. doi: 10.1016/j.jtcvs.2005.04.003

5. Brown JW, Ruzmetov M, Rodefeld MD, Vijay P, Turrentine WM. Right ventricular outflow tract reconstruction with an allograft conduit in non-ross patients: risk factors for allograft dysfunction and failure. Ann Thorac Surg. (2005) 80:655-63; discussion 663-4. doi: 10.1016/j.athoracsur.2005.02.053

6. Karamlou T, Ungerleider RM, Alsoufi B, Burch G, Silberbach M, Reller $\mathrm{M}$, et al. Oversizing pulmonary homograft conduits does not significantly decrease allograft failure in children. Eur J Cardiothorac Surg. (2005) 27:54853. doi: 10.1016/j.ejcts.2004.12.054

7. Wells WJ, Arroyo H Jr, Bremner RM, Wood J, Starnes AV. Homograft conduit failure in infants is not due to somatic outgrowth. J Thorac Cardiovasc Surg. (2002) 124:88-96. doi: 10.1067/mtc.2002.121158

8. Michler RE, Chen JM, Quaegebeur MJ. Novel technique for extending the use of allografts in cardiac operations. Ann Thorac Surg. (1994) 57:837. doi: 10.1016/0003-4975(94)90369-7

9. Cleuziou J, Vitanova K, Kasnar-Samprec J, Horer J, Lange R, Schreiber C. Durability of down-sized homografts for the reconstruction of the right ventricular outflow tract. Eur J Cardiothorac Surg. (2016) 49:14215. doi: 10.1093/ejcts/ezv418

10. Romeo JLR, Papageorgiou G, van de Woestijne PC, Takkenberg JJM, Westenberg LEH, van Beynum I, et al. Downsized cryopreserved and standard-sized allografts for right ventricular outflow tract reconstruction in children: long-term single-institutional experience. Interact Cardiovasc Thorac Surg. (2018) 27:257-63. doi: 10.1093/icvts/ivy057

11. Vitanova K, Cleuziou J, Horer J, Kasnar-Samprec J, Vogt M, Schreiber C, et al. Which type of conduit to choose for right ventricular outflow tract reconstruction in patients below 1 year of age dagger. Eur J Cardiothorac Surg. (2014) 46:961-6; discussion 966. doi: 10.1093/ejcts/ezu080

12. Falchetti A, Demanet $H$, Dessy $H$, Melot C, Pierrakos C, Wauthy P. Contegra versus pulmonary homograft for right ventricular outflow tract reconstruction in newborns. Cardiol Young. (2019) 29:505-10. doi: 10.1017/S1047951119000143

13. Poynter JA, Eghtesady P, McCrindle BW, Walters HL 3rd, Kirshbom $\mathrm{PM}$, Blackstone $\mathrm{EH}$, et al. Congenital heart surgeons: association of pulmonary conduit type and size with durability in infants and young children. Ann Thorac Surg. (2013) 96:1695-701; discussion 1701-2. doi: 10.1016/j.athoracsur.2013.05.074

14. Herrmann JL, Larson EE, Mastropietro CW, Rodefeld MD, Turrentine MW, Nozaki R, et al. Right ventricular outflow tract reconstruction in infant truncus arteriosus: a 37-year experience. Ann Thorac Surg. (2020) 110:6307. doi: 10.1016/j.athoracsur.2019.11.023

15. Patel PM, Herrmann JL, Rodefeld MD, Turrentine MW, Brown WJ. Bovine jugular vein conduit versus pulmonary homograft in the Ross operation. Cardiology in the Young. (2019) 30:323-7. doi: 10.1017/S1047951119 003007

16. Patel PM, Tan C, Srivastava N, Herrmann JL, Rodefeld MD, Turrentine MW, et al. Bovine jugular vein conduit: a mid- to long-term institutional review. World J Pediatr Congenit Heart Surg. (2018) 9:489-95. doi: 10.1177/2150135118779356

17. Miyazaki T, Yamagishi M, Maeda Y, Yamamoto Y, Taniguchi S, Sasaki Y, et al. Expanded polytetrafluoroethylene conduits and patches with bulging sinuses and fan-shaped valves in right ventricular outflow tract reconstruction: multicenter study in Japan. J Thorac Cardiovasc Surg. (2011) 142:11229. doi: 10.1016/j.jtcvs.2011.08.018
18. Yamashita E, Yamagishi M, Miyazaki T, Maeda Y, Yamamoto Y, Kato N, et al. Smaller-sized expanded polytetrafluoroethylene conduits with a fan-shaped valve and bulging sinuses for right ventricular outflow tract reconstruction. Ann Thorac Surg. (2016) 102:1336-44. doi: 10.1016/j.athoracsur.2016.03.027

19. Miyazaki T, Yamagishi M, Maeda Y, Taniguchi S, Fujita S, Hongu $\mathrm{H}$, et al. Long-term outcomes of expanded polytetrafluoroethylene conduits with bulging sinuses and a fan-shaped valve in right ventricular outflow tract reconstruction. J Thorac Cardiovasc Surg. (2018) 155:2567-76. doi: 10.1016/j.jtcvs.2017.12.137

20. Behrendt DM, Dick $M$ 3rd. Truncus repair with a valveless conduit in neonates. J Thorac Cardiovasc Surg. (1995) 110 (4 Pt 1):1148-50. doi: 10.1016/S0022-5223(05)80189-8

21. Metras D, Fouilloux V, Mace L, Fraisse A, Kreitmann B. Right ventricular outflow repair: the aortic autograft technique procures the best late results in the transposition complex. Eur J Cardiothorac Surg. (2011) 40:6148. doi: $10.1016 /$ j.ejcts.2010.12.061

22. Ross DN, Somerville J. Correction of pulmonary atresia with a homograft aortic valve. Lancet. (1966) 2:1446-7. doi: 10.1016/S0140-6736(66)90600-3

23. O'Brien MF, Stafford EG, Gardner MA, Pohlner PG, McGiffin CD. A comparison of aortic valve replacement with viable cryopreserved and fresh allograft valves, with a note on chromosomal studies. J Thorac Cardiovasc Surg. (1987) 94:812-23. doi: 10.1016/S0022-5223(19)36152-5

24. O'Brien MF, Goldstein S, Walsh S, Black KS, Elkins R, Clarke D. The synergraft valve: a new acellular (nonglutaraldehyde-fixed) tissue heart valve for autologous recellularization first experimental studies before clinical implantation. Semin Thorac Cardiovasc Surg. (1999) 11 (4 Suppl 1), 194-200.

25. Takahashi Y, Tsutsumi Y, Monta O, Kato Y, Kohshi K, Sakamoto T, et al. Expanded polytetrafluoroethylene-valved conduit with bulging sinuses for right ventricular outflow tract reconstruction in adults. Gen Thorac Cardiovasc Surg. (2010) 58:14-8. doi: 10.1007/s11748-009-0527-9

26. Mainwaring RD, Patrick WL, Punn R, Palmon M, Reddy VM, Hanley LF. Fate of right ventricle to pulmonary artery conduits after complete repair of pulmonary atresia and major aortopulmonary collaterals. Ann Thorac Surg. (2015) 99:1685-91. doi: 10.1016/j.athoracsur.2014.12.071

27. Nelson JS, Pasquali SK, Pratt CN, Yu S, Donohue JE, Loccoh E, et al. Long-term survival and reintervention after the ross procedure across the pediatric age spectrum. Ann Thorac Surg. (2015) 99:2086-94; discussion 2094-5. doi: 10.1016/j.athoracsur.2015.02.068

28. Francois K, De Groote K, Vandekerckhove K, De Wilde H, De Wolf D, Bove T. Small-sized conduits in the right ventricular outflow tract in young children: bicuspidalized homografts are a good alternative to standard conduits. Eur J Cardiothorac Surg. (2018) 53:409-15. doi: 10.1093/ejcts/ezx354

29. Lu T, Huang Y, Liu Y, Shen Y, Qiao Y, Zhang Y. Effects of cryopreservation on tracheal allograft antigenicity in dogs. J Thorac Dis. (2017) 9:203847. doi: $10.21037 /$ jtd.2017.06.67

30. Sarikouch S, Horke A, Tudorache I, Beerbaum P, Westhoff-Bleck M, Boethig D, et al. Decellularized fresh homografts for pulmonary valve replacement: a decade of clinical experience. Eur J Cardiothorac Surg. (2016) 50:28190. doi: 10.1093/ejcts/ezw050

31. Karamlou T, Blackstone EH, Hawkins JA, Jacobs ML, Kanter KR, Brown JW, et al. Pulmonary conduit working group for the members of the congenital heart surgeons: can pulmonary conduit dysfunction and failure be reduced in infants and children less than age 2 years at initial implantation? J Thorac Cardiovasc Surg. (2006) 132:829-38. doi: 10.1016/j.jtcvs.2006.06.034

32. Quintessenza JA. Polytetrafluoroethylene pulmonary valve conduit implantation for chronic pulmonary insufficiency. Cardiol Young. (2014) 24:1101-3. doi: 10.1017/S1047951114002200

33. Cebotari S, Tudorache I, Ciubotaru A, Boethig D, Sarikouch S, Goerler A, et al. Use of fresh decellularized allografts for pulmonary valve replacement may reduce the reoperation rate in children and young adults: early report. Circulation. (2011) 124 (11 Suppl), S115-23. doi: 10.1161/CIRCULATIONAHA.110.012161

34. Shahanavaz S, Qureshi AM, Levi DS, Boudjemline Y, Peng LF, Martin MH, et al. Transcatheter pulmonary valve replacement with the melody valve in small diameter expandable right ventricular outflow tract conduits. JACC Cardiovasc Interv. (2018) 11:554-64. doi: 10.1016/j.jcin.2018.01.239

35. Boethig D, Goerler H, Westhoff-Bleck M, Ono M, Daiber A, Haverich A, et al. Evaluation of 188 consecutive homografts implanted in 
pulmonary position after 20 years. Eur J Cardiothorac Surg. (2007) 32:133-42. doi: 10.1016/j.ejcts.2007.02.025

36. Romeo JLR, Mokhles MM, van de Woestijne P, de Jong P, van den Bosch A, van Beynum IM, et al. Long-term clinical outcome and echocardiographic function of homografts in the right ventricular outflow tractdagger. Eur J Cardiothorac Surg. (2019) 55:518-26. doi: 10.1093/ejcts/ezy265

37. Kaza AK, Lim HG, Dibardino DJ, Bautista-Hernandez V, Robinson J, Allan $\mathrm{C}$, et al. Long-term results of right ventricular outflow tract reconstruction in neonatal cardiac surgery: options and outcomes. J Thorac Cardiovasc Surg. (2009) 138:911-6. doi: 10.1016/j.jtcvs.2008.10.058

38. Clarke DR, Campbell DN, Hayward AR, Bishop AD. Degeneration of aortic valve allografts in young recipients. J Thorac Cardiovasc Surg. (1993) 105:93441; discussion 941-2. doi: 10.1016/S0022-5223(19)34168-6

39. Ruzmetov M, Shah JJ, Geiss DM, Fortuna SR. Decellularized versus standard cryopreserved valve allografts for right ventricular outflow tract reconstruction: a single-institution comparison. J Thorac Cardiovasc Surg. (2012) 143:543-9. doi: 10.1016/j.jtcvs.2011.12.032

40. Bibevski S, Ruzmetov M, Fortuna RS, Turrentine MW, Brown JW, Ohye GR. Performance of synergraft decellularized pulmonary allografts compared with standard cryopreserved allografts: results from multiinstitutional data. Ann Thorac Surg. (2017) 103:869-74. doi: 10.1016/j.athoracsur.2016.07.068

41. Cebotari S, Lichtenberg A, Tudorache I, Hilfiker A, Mertsching H, Leyh $\mathrm{R}$, et al. Clinical application of tissue engineered human heart valves using autologous progenitor cells. Circulation. (2006) 114 (1 Suppl):I1327. doi: 10.1161/CIRCULATIONAHA.105.001065

42. Boethig D, Horke A, Hazekamp M, Meyns B, Rega F, Van Puyvelde J, et al. A European study on decellularized homografts for pulmonary valve replacement: initial results from the prospective ESPOIR Trial and ESPOIR Registry datadagger. Eur J Cardiothorac Surg. (2019) 56:5039. doi: 10.1093/ejcts/ezz054

43. Sandica E, Boethig D, Blanz U, Goerg R, Haas NA, Laser KT, et al. Bovine jugular veins versus homografts in the pulmonary position: an analysis across two centers and 711 patients-conventional comparisons and time status graphs as a new approach. Thorac Cardiovasc Surg. (2016) 64:2535. doi: 10.1055/s-0035-1554962

44. Hickey EJ, McCrindle BW, Blackstone EH, Yeh T Jr, Pigula F, Clarke D, et al. Jugular venous valved conduit (Contegra) matches allograft performance in infant truncus arteriosus repair. Eur J Cardiothorac Surg. (2008) 33:8908. doi: 10.1016/j.ejcts.2007.12.052

45. Buckley JR, Amula V, Sassalos P, Costello JM, Smerling AJ, Iliopoulos I, et al. Collaborative research in pediatric cardiac intensive care: multicenter analysis of early childhood outcomes after repair of truncus arteriosus. Ann Thorac Surg. (2019) 107:553-9. doi: 10.1016/j.athoracsur.2018.08.094

46. Mery CM, Guzman-Pruneda FA, De Leon LE, Zhang W, Terwelp MD, Bocchini CE, et al. Risk factors for development of endocarditis and reintervention in patients undergoing right ventricle to pulmonary artery valved conduit placement. J Thorac Cardiovasc Surg. (2016) 151:432-9, 441 e1-2. doi: 10.1016/j.jtcvs.2015.10.069

47. Haas NA, Bach S, Vcasna R, Laser KT, Sandica E, Blanz U, et al. The risk of bacterial endocarditis after percutaneous and surgical biological pulmonary valve implantation. Int J Cardiol. (2018) 268, 55-60. doi: 10.1016/j.ijcard.2018.04.138

48. Beckerman Z, De Leon LE, Zea-Vera R, Mery CM, Fraser CD Jr. High incidence of late infective endocarditis in bovine jugular vein valved conduits. J Thorac Cardiovasc Surg. (2018) 156:728-34 e2. doi: 10.1016/j.jtcvs.2018.03.156

49. Sharma A, Cote AT, Hosking MCK, Harris CK. A systematic review of infective endocarditis in patients with bovine jugular vein valves compared with other valve types. JACC Cardiovasc Interv. (2017) 10:144958. doi: 10.1016/j.jcin.2017.04.025

50. Yamagishi $\mathrm{M}$, Kurosawa $\mathrm{H}$. Outflow reconstruction of tetralogy of Fallot using a Gore-Tex valve. Ann Thorac Surg. (1993) 56:1414-6; discussion 1416-7. doi: 10.1016/0003-4975(93)90700-R

51. Turrentine MW, McCarthy RP, Vijay P, Fiore AC, Brown WJ. Polytetrafluoroethylene monocusp valve technique for right ventricular outflow tract reconstruction. Ann Thorac Surg. (2002) 74:2202-5. doi: 10.1016/S0003-4975(02)03844-4
52. Yamamoto Y, Yamagishi M, Miyazaki T, Asada S, Maeda Y, Yaku H, et al. Modification of expanded polytetrafluoroethylene valved conduit using the thin-type leaflets. J Thorac Cardiovasc Surg. (2018) 156:1629-36 e3. doi: 10.1016/j.jtcvs.2018.04.107

53. Miyazaki T, Yamagishi M, Yamamoto Y, Itatani K, Asada S, Fujita S, et al. Use of an expanded polytetrafluoroethylene valved patch with a sinus in right ventricular outflow tract reconstructiondagger. Eur J Cardiothorac Surg. (2019) 56:671-8. doi: 10.1093/ejcts/ezz089

54. Shinkawa T, Tang X, Gossett JM, Mustafa T, Hategekimana F, Watanabe F, et al. Valved polytetrafluoroethylene conduits for right ventricular outflow tract reconstruction. Ann Thorac Surg. (2015) 100:129-37; discussion 137. doi: 10.1016/j.athoracsur.2015.02.114

55. Sharifulin R, Bogachev-Prokophiev A, Demin I, Zheleznev S, Pivkin A, Afanasyev A, et al. Right ventricular outflow tract reconstruction using a polytetrafluoroethylene conduit in Ross patients. Eur J Cardiothorac Surg. (2018) 54:427-33. doi: 10.1093/ejcts/ezy128

56. Quintessenza JA, Jacobs JP, Chai PJ, Morell VO, Lindberg H. Polytetrafluoroethylene bicuspid pulmonary valve implantation: experience with 126 patients. World J Pediatr Congenit Heart Surg. (2010) 1:20-7. doi: 10.1177/2150135110361509

57. Lee C, Lee CH, Kwak GJ. Polytetrafluoroethylene bicuspid pulmonary valve replacement: a 5-year experience in 119 patients with congenital heart disease. Ann Thorac Surg. (2016) 102:163-9. doi: 10.1016/j.athoracsur.2016.01.056

58. Choi KH, Sung SC, Kim H, Lee HD, Kim G, Ko H. Late results of right ventricular outflow tract reconstruction with a bicuspid expanded polytetrafluoroethylene valved conduit. J Card Surg. (2018) 33:36-40. doi: 10.1111/jocs.13507

59. Mercer CW, West SC, Sharma MS, Yoshida M, Morell OV. Polytetrafluoroethylene conduits versus homografts for right ventricular outflow tract reconstruction in infants and young children: an institutional experience. J Thorac Cardiovasc Surg. (2018) 155:2082-91. e1. doi: 10.1016/j.jtcvs.2017.11.107

60. Seese LM, Turbendian HK, Castrillon CED, Morell OV. The fate of homograft versus polytetrafluoroethylene conduits after neonatal truncus arteriosus repair. World J Pediatr Congenit Heart Surg. (2020) 11:1417. doi: $10.1177 / 2150135119888141$

61. Cheatham JP, Hellenbrand WE, Zahn EM, Jones TK, Berman DP, Vincent JA, et al. Clinical and hemodynamic outcomes up to 7 years after transcatheter pulmonary valve replacement in the US melody valve investigational device exemption trial. Circulation. (2015) 131:196070. doi: 10.1161/CIRCULATIONAHA.114.013588

62. Sinha P, Talwar S, Moulick A, Jonas R. Right ventricular outflow tract reconstruction using a valved femoral vein homograft. J Thorac Cardiovasc Surg. (2010) 139:226-8. doi: 10.1016/j.jtcvs.2008.10.018

63. Schiller O, Sinha P, Zurakowski D, Jonas AR. Reconstruction of right ventricular outflow tract in neonates and infants using valved cryopreserved femoral vein homografts. J Thorac Cardiovasc Surg. (2014) 147:8749. doi: 10.1016/j.jtcvs.2013.11.006

64. Carreon CK, Benini A, Baird C, Hoganson D, Borisuk M, Emani S, et al. Pathology of valved venous homografts used as right ventricle-to-pulmonary artery conduits in congenital heart disease surgery. J Thorac Cardiovasc Surg. (2019) 157:342-350. e3. doi: 10.1016/j.jtcvs.2018.08.102

65. Croti UA, BraileDM, Kozak ACLFBM, Beani L. Rastelli procedure with decellularized pulmonary homograft. Braz J Cardiovasc Surg. (2006) 21:3567. doi: 10.1590/S0102-76382006000300018

66. Yuan H, Chen C, Liu Y, Lu T, Wu Z. Strategies in cell-free tissueengineered vascular grafts. J Biomed Mater Res A. (2020) 108:42645. doi: 10.1002/jbm.a.36825

67. Shin'oka T, Matsumura G, Hibino N, Naito Y, Watanabe M, Konuma T, et al. Midterm clinical result of tissue-engineered vascular autografts seeded with autologous bone marrow cells. J Thorac Cardiovasc Surg. (2005) 129:13308. doi: 10.1016/j.jtcvs.2004.12.047

68. Hibino N, McGillicuddy E, Matsumura G, Ichihara Y, Naito Y, Breuer C, et al. Late-term results of tissue-engineered vascular grafts in humans. J Thorac Cardiovasc Surg. (2010) 139:431-6, 436. e1-2. doi: 10.1016/j.jtcvs.2009.09.057

69. Bennink G, Torii S, Brugmans M, Cox M, Svanidze O, Ladich E, et al. Virmani. A novel restorative pulmonary valved conduit in a chronic 
sheep model: mid-term hemodynamic function and histologic assessment. $J$ Thorac Cardiovasc Surg. (2018) 155:2591-601. e3. doi: 10.1016/j.jtcvs.2017. 12.046

70. Gilbert CL, Gnanapragasam J, Benhaggen R, Novick MW. Novel use of extracellular matrix graft for creation of pulmonary valved conduit. World J Pediatr Congenit Heart Surg. (2011) 2:495-501. doi: 10.1177/2150135111406142

71. Mosala Nezhad Z, Poncelet A, de Kerchove L, Fervaille C, Banse X, Bollen X, et al. CorMatrix valved conduit in a porcine model: long-term remodelling and biomechanical characterization. Interact Cardiovasc Thorac Surg. (2017) 24:90-8. doi: 10.1093/icvts/ivw314

72. van Rijswijk JW, Talacua $H$, Mulder K, van Hout GPJ, Bouten CVC, Grundeman PF, et al. Failure of decellularized porcine small intestinal submucosa as a heart valved conduit. J Thorac Cardiovasc Surg. (2020). doi: 10.1016/j.jtcvs.2019.09.164

73. Ghorbel MT, Jia H, Swim MM, Iacobazzi D, Albertario A, Zebele C, et al. Reconstruction of the pulmonary artery by a novel biodegradable conduit engineered with perinatal stem cellderived vascular smooth muscle cells enables physiological vascular growth in a large animal model of congenital heart disease. Biomaterials. (2019) 217:119284. doi: 10.1016/j.biomaterials.2019.1 19284

74. Lu WD, Zhang M, Wu ZS, Hu HT. Decellularized and photooxidatively crosslinked bovine jugular veins as potential tissue engineering scaffolds. Interact Cardiovasc Thorac Surg. (2009) 8:301-5. doi: 10.1510/icvts.2008.194076

75. Lu WD, Zhang $\mathrm{M}, \mathrm{Wu} \mathrm{ZS}, \mathrm{Hu} \mathrm{TH}, \mathrm{Xu} \mathrm{ZJ}$, Liu W, et al. The performance of photooxidatively crosslinked acellular bovine jugular vein conduits in the reconstruction of connections between pulmonary arteries and right ventricles. Biomaterials. 31:2934-43. doi: 10.1016/j.biomaterials.2009.12.046

76. Lu WD, Wang AP, Wu ZS, Zhang M, Hu TH, Lei GY, et al. Calcification resistance for photooxidatively crosslinked acellular bovine jugular vein conduits in right-side heart implantation. J Biomed Mater Res A. (2012) 100:2644-53. doi: 10.1002/jbm.a.34203

77. Qian T, Wu ZS, Hu JG, Yang YF, Wu Q, Lu T, et al. Midterm outcomes of crosslinked acellular bovine jugular vein conduit for right ventricular outflow tract reconstruction. Front Pediatr. (2021) 9:725030. doi: 10.3389/fped.2021.725030

Conflict of Interest: The authors declare that the research was conducted in the absence of any commercial or financial relationships that could be construed as a potential conflict of interest.

Publisher's Note: All claims expressed in this article are solely those of the authors and do not necessarily represent those of their affiliated organizations, or those of the publisher, the editors and the reviewers. Any product that may be evaluated in this article, or claim that may be made by its manufacturer, is not guaranteed or endorsed by the publisher.

Copyright (C) 2021 Qian, Yuan, Chen, Liu, Lu, Huang and Wu. This is an open-access article distributed under the terms of the Creative Commons Attribution License (CC $B Y)$. The use, distribution or reproduction in other forums is permitted, provided the original author(s) and the copyright owner(s) are credited and that the original publication in this journal is cited, in accordance with accepted academic practice. No use, distribution or reproduction is permitted which does not comply with these terms. 